quotations without giving a citation for their sources. The book has no foot- or endnotes.

Vernon follows a general "triumphalist" approach to the Spanish mission effort in his discussions of the broad events of the Jesuit, Franciscan and Dominican occupations of the peninsula. This approach begins with the assumption that the mission program was designed "not only to save the souls of the heathen, but also to teach them to survive in the modern world" (Introduction, p. xiv). This results in apologist statements such as: "Many of the Christian religious believe that this tremendous undertaking was necessary and worthwhile because the missionaries self-sacrificing work, while not successful in a material way, did insure that thousands of heathens would be admitted to the Kingdom of Heaven" (Introduction, p. xiv). Vernon includes modern estimates that the population of the peninsula dropped from perhaps 30,000 natives at the beginning of the Jesuit missionization program in 1697 to less than 7,000 in 1767.

Las Misiones Antiguas is best used in conjunction with Harry Crosby's Antigua California: Mission and Colony on the Peninsular Frontier, I697-I768, a detailed history of the Jesuit mission program in Baja California. Crosby's work provides the exacting historical detail, and Vernon's book gives beautiful pictures and thumbnail written sketches of the individual missions mentioned in Crosby's text. Used in this way, or as an explorer's guide for trips around the peninsula, Vernon's book is an excellent companion.

\author{
s \\ Misiones para Chibuahua \\ Clara Bargellini (coord.), fotografías de \\ Libertad Villarreal, \\ México, México Desconocido, 2004 \\ por \\ CYNTHIA RADDING
}

Los tres textos que conforman este libro, ilustrado con más de un centenar de fotografías y tres mapas, proveen al lector de una interpretación a la vez comprometida y crítica de la huella histórica de las misiones en el devenir de Chihuahua y en el legado cultural de los chihuahuenses. Los autores coinciden, además, en que la historia que les fue encomendada no se limita a los linderos de Chihuahua, sino que abarca necesariamente la amplia región que hoy día incluye el norte de México y el suroeste de Estados Unidos. Me interesaron especialmente las muchas referencias a las rutas de comercio, migración y expediciones militares entre Sonora y Nueva Vizcaya, pasando por los reales de minas de Ostimuri, Parral, Cusihuirachi y —desde luego- Chihuahua. Asimismo, el énfasis en los caminos que ligaban a Chihuahua con Nuevo México, y el tráfico en ambas direcciones, nos obliga a todos los estudiosos de estos temas a cuestionar las aseveraciones tradicionales de aislamiento o de fronteras inhóspitas asociadas con el gran septentrión de la Nueva España.

En la introducción a Misiones para Chihuahua, Clara Bargellini expone que el propósito de este libro es demostrar el aporte de las misiones a la historia de la región, objetivo que los tres autores cumplen cabalmen- 


\section{DOI: http://dx.doi.org/10.22201/iie.18703062e.2007.91.2254}

\section{6}

LIB ROS te. Explican cómo avanzó la obra misional, tanto franciscana como jesuítica, a la par de la colonización civil - $-\mathrm{y}$, de hecho, la una no se entiende sin la otra. Las preguntas que me quedan conciernen al papel de los indígenas en la historia de las misiones, el carácter de las comunidades que se formaron en las reducciones o a su alrededor, y las similitudes y contrastes entre las diferentes provincias del noroeste, norte y noreste de la Nueva España. Salvador Álvarez argumenta que las misiones en la Tarahumara Baja y Alta — con la posible excepción de Papigochi- y en la Conchería no se consolidaron en pueblos de indios con las instituciones connotadas de cabildo, cofradía y caja de comunidad. Declara, aún más, que en ninguna de las provincias de la Nueva Vizcaya y Sonora se registraban títulos primordiales de tierras para las misiones, excepto en Papigochi. Por lo que se refiere a Sonora, me consta, a partir de los documentos que he podido analizar en los archivos de Instrumentos Públicos de Jalisco, la Audiencia de Guadalajara (en la Biblioteca Pública de Jalisco), el Archivo General de la Nación y el Fondo Franciscano de la Biblioteca Nacional, que los pimas de Oviachic, Nuri y Movas, en Sonora, sacaron títulos de composición para sus tierras frente al crecimiento de la población hispano-mestiza y la expansión de las haciendas ganaderas durante la primera mitad del siglo XVIII. Asimismo, gobernadores y "capitanes generales" ópatas, pimas y yaquis se enfrentaron a los gobernadores, intendentes y comandantes de presidios para reclamar su remuneración como auxiliares militares y defender la integridad de sus tierras. El papel de los cabildos fue notado explícitamente por los misioneros que servían en la zona y aflora en los documentos, donde se refiere que los gobernadores y alcaldes indígenas se acerca- ron a las autoridades espańolas de la provincia "en nombre del común y de todos los hijos del pueblo". Sin negar el hecho de que los misioneros ejercieron una gran influencia en la selección de estos oficiales de cabildo, me parece importante subrayar la presencia efectiva de los cabildos en el gobierno interno y en la vida ritual de los pueblos, su representatividad hacia afuera y el concepto del común que, para el siglo XviII, si no antes, constituía un principio central en la ideología de los indios de la misión. Su ausencia en la Tarahumara y la Conchería, si es así, es necesario tomarla en cuenta como punto de comparación, no de generalización, con las demás provincias del septentrión novohispano.

Chantal Cramaussel hace una síntesis admirable de las etapas de colonización civil que llegaron, por diferentes rutas, a la fundación de los reales de Santa Rosa de Cusihuiriachi y San Felipe de Chihuahua. Entreteje magistralmente las historias paralelas de las misiones jesuitas y franciscanas en la región con la del avance empresarial e imperial de los españoles, demostrando su interdependencia. Su énfasis en la coacción de la mano de obra indígena, ya fuera como presos y cautivos o bien como indios sacados de los pueblos por los mandamientos del repartimiento, se fundamenta sin duda en los documentos, pero representa a los indígenas propios y foráneos como objetos de las misiones y empresas españolas, no como sujetos de su historia.

Clara Bargellini sitúa la arquitectura y el arte de las misiones de Chihuahua en el contexto de las tradiciones y de las técnicas de construcción y realización artística en Europa y la Nueva España de la época. Nos enseña que fueron las devociones piadosas de los misioneros y de los donantes particulares las que guiaron la selección de imágenes que 


\section{DOI: http://dx.doi.org/10.22201/iie.18703062e.2007.91.2254}

adornaron los retablos, fachadas y paredes de los espacios litúrgicos que constituyeron las iglesias, los atrios y las vías procesionales de las misiones. Bargellini asevera que los trabajadores calificados venían probablemente de México, Zacatecas y Durango, y logra identificar a algunos maestros de obra, como Simón de los Santos, quien dirigió la construcción de la iglesia jesuita de tres naves dedicada al Nombre de Jesús de Carichí y dejó capacitados a algunos canteros indígenas después de su estancia de varios años en la misión. Si bien la mayoría de los indios que trabajaron en la construcción de los templos se dedicaron a los trabajos gruesos de hacer adobe y colocar tabiques, vale la pena preguntarnos cómo se hicieron presentes los espacios, las tallas en madera, la cantera labrada y las imágenes de los santos en la cosmología de los rarámuris y otros grupos indígenas que participaron en la vida ritual de las misiones aunque no hayan vivido en ellas en forma permanente.

Resumiendo brevemente las tesis centrales del libro, encontramos que los autores hacen hincapié en los siguientes temas:

- Las misiones no son una institución fronteriza independiente, sino que su fundación y desenvolvimiento deben entenderse como parte de la colonización civil en el gran septentrión de la Nueva España.

- Las misiones comprendían a los pueblos, como centros de evangelización y obras magistrales de arte y arquitectura. Fungían como fuente de recursos indispensable en comestibles y mano de obra para la economía colonial en la minería, las haciendas de granos y ganado y el comercio.

- Las influencias y dependencias eran recíprocas entre las misiones y los asentamientos españoles para el envío de granos, ganado y mercancías, para las remesas de plata desde los reales de Santa Bárbara, Parral, Cusihuiriachi y Chihuahua y para el movimiento de gente.

- La geografía natural y la cultural juegan un papel importante en esta historia de las misiones. El desierto de Chihuahua, las faldas y cordilleras orientales de la Sierra Madre Occidental, los ríos y fuentes de agua y tierras laborables, los caminos y las rutas de comercio que ligaban a la provincia de Chihuahua con las regiones aledañas de Durango y Zacatecas, con el sur de Sonora, al poniente, y de Nuevo México, al norte.

- La reducción de poblaciones indígenas desde diversos grupos y naciones en las misiones no puede separarse de la historia violenta de las conquistas militares, la esclavitud, las instituciones de encomienda y repartimiento, ni de las repetidas rebeliones de los indios y su represión. La mortandad indígena, debido a los trabajos forzosos, los traslados por largas distancias y el contagio de las epidemias, frente al crecimiento gradual de la población no indígena - españoles, mestizos, mulatos-, constituía una dinámica ineludible en las luchas por dominar y resistir el orden colonial.

- El mestizaje étnico, cultural y social se produjo en las misiones y asentamientos coloniales entre diferentes grupos indígenas traídos por la fuerza o reducidos a los pueblos de misión por voluntad propia, así como entre los indios y las diversas clases y castas de españoles, mestizos, mulatos y otros que se mezclaron en los reales de minas, las haciendas y los pueblos de misión.

- Las fuentes de inspiración y los lugares de producción del arte que se admira en las misiones de Chihuahua - en su construcción y en las pinturas y esculturas de 


\section{8}

LI B ROS

arte sacro- tenían varios orígenes, desde Roma y el seno de las órdenes religiosas franciscana y jesuita que administraban las misiones, hasta la capital del virreinato en México, la ciudad colonial de Zacatecas y las adaptaciones arquitectónicas en los pueblos de Nuevo México. Artistas, arquitectos, maestros de obra y artesanos -entre canteros, carpinteros, albañiles - llegaron a Chihuahua o pasaron por la provincia, y contribuyeron a las obras híbridas y tan originales que combinaron estilos y elementos de diferentes periodos e influencias. 